\title{
Antimicrobial Resistance and Virulence Genes Presence in Escherichia coli Strains Isolated from Gomso Bay, Korea
}

\author{
Kwon-Sam Park* \\ Department of Food Science and Biotechnology, College of Ocean Science and Technology, Kunsan National University, Gunsan \\ 573-701, Korea
}

\begin{abstract}
In total, 131 Escherichia coli isolates from surface seawater of the Gomso Bay, of Korea, were analyzed for their susceptibility to 22 different antimicrobials and for genes associated with antimicrobial resistance and virulence. According to the disk diffusion susceptibility test, the resistance to tetracycline was most prevalent (33.6\%), followed by that to ampicillin (22.1\%), ticarcillin (22.1\%), and trimethoprim (16.8\%). More than $46.6 \%$ of the isolates were resistant to at least one antimicrobial, and $22.9 \% \mathrm{were}$ resistant to three or more classes of antimicrobials; these were consequently defined as multidrug resistant. We further found that 29 ampicillin-resistant isolates possessed genes encoding TEM-type (93.1\%) and SHV-type (6.9\%) $\beta$-lactamases. Among the 44 tetracycline-resistant isolates, tet $A$ and tet $C$ were found in $35(79.5 \%)$ and $19(43.2 \%)$, respectively, whereas tetB was detected in only three isolates $(6.8 \%)$. With regard to virulence genes, merely $0.8 \%(n=1)$ and $2.3 \%(n=3)$ of the isolates were positive for the enteroaggregative $E$. coli-associated plasmid ( $p C V D 432)$ gene and the enteropathogenic E. coli-specific attaching and effacing (eae) gene, respectively. Overall, these results not only provide novel insight into the necessity for seawater sanitation in Gomso Bay, but they help reduce the risk of contamination of antimicrobial-resistant bacteria.
\end{abstract}

Key words: Antimicrobial resistance, Escherichia coli, Gomso Bay, Virulence genes

\section{Introduction}

Escherichia coli is a facultative anaerobic bacterium found in the normal flora of the intestinal tract of humans and animals; in contrast, it has also been implicated in infectious diseases (Rosas et al., 2006). Currently, E. coli are widely used as a sanitation indicator of microbiological contamination in water and food (Lang et al., 1999). While, E. coli is harmless in general, certain virulent strains are common causes of infectious diarrhea and other enteric diseases (Clements et al., 2012). Currently, the following E. coli pathotypes have been recognized to cause diarrhea in humans: EPEC, enteropathogenic E. coli; EIEC, enteroinvasive E. coli; STEC, Shiga toxin-producing E. coli; EAEC, enteroaggregative E. coli; ETEC, enterotoxigenic E. coli; and DAEC, diffusely adhering E. coli
(Turner et al., 2006).

For livestock farming, antimicrobial agents are abundantly used not only for medical treatment and prophylaxis of bacterial infections but also in the animals' food to promote growth, which has resulted in an increase in antimicrobial-resistant bacterial strains (Aarestrup, 2005; Sapkota et al., 2008). The critical factor in the development of antimicrobial resistance is the ability of the bacteria to acquire and disseminate exogenous genes via mobile genetic elements, such as plasmids, transposons, DNA insertion elements, and genomic islands (Rowe-Magnus et al., 2002). Horizontal gene transfer is one of the most common mechanisms, by which antimicrobial resistance traits are transferred from one organism to another
http://dx.doi.org/10.5657/FAS.2013.0221

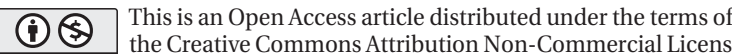
(http://creativecommons.org/licenses/by-nc/3.0/) which permits unrestricted non-commercial use, distribution, and reproduction in any medium, provided the original work is properly cited.
Received 21 August 2013; Revised 24 October 2013

Accepted 28 October 2013

*Corresponding Author

E-mail: parkks@kunsan.ac.kr 
(Martinez, 2009). Since the discovery of integrons, a unique mechanism for the dissemination of antibiotic resistance genes (Stokes and Hall, 1989), the increase in bacterial strains resistant to several antimicrobial agents has raised public health concerns about treatment options, heath care costs, and foodborne illness (Hammerum and Heuer, 2009). Food contamination of antimicrobial-resistant bacteria could be a major public health threat, due to the possibility that the responsible genes, which are carried on mobile genetic elements, may be transferred to other bacteria that confer high risks to human health (Rowe-Magnus et al., 2002). E. coli strains, in particular, are candidate vehicles for such genetic transfers, not only due to their diversity but also because they exist as common microflora of the gastrointestinal tracts of humans and animals (Clements et al., 2012).

In Korea, numerous studies have focused on antimicrobial resistance patterns and genes in $E$. coli strains isolated from various sources, including humans, food and animals (You et al., 2006; Koo and Woo, 2011; Ryu et al., 2012a). However, very few of these studies provided adequate data regarding the prevalence of $E$. coli in seawater or seafood.

In this study, E. coli strains isolated from surface seawater of Gomso Bay, on the west coast of Korea, were characterized for their prevalence, antimicrobial resistance, and virulence gene expression using the disk diffusion method and polymerase chain reaction (PCR).

\section{Materials and Methods}

\section{E. coli isolation and identification}

In total, 131 environmental strains of $E$. coli were isolated from the surface seawater of Gomso Bay, Jeollabuk-do, Korea, between May and December of 2012. Seawater samples collected from sampling stations were transported within $4 \mathrm{~h}$ to the laboratory in ice-cold containers. The number of total coliform and fecal coliform bacteria was determined using the most probable number (MPN) method (American Public Health Association, 1970). Seawater was inoculated with lauryl tryptose broth (Difco; Becton, Dickinson and Co., Franklin Lakes, NJ, USA) and incubated for $48 \pm 2 \mathrm{~h}$ at $35^{\circ} \mathrm{C}$. One loop from each gas-positive tube was inoculated with Brilliant Green Bile Broth (Difco) and EC medium (Difco), and incubated for $48 \pm 2 \mathrm{~h}$ at $35^{\circ} \mathrm{C}$ or $24 \pm 2 \mathrm{~h}$ at $44.5 \pm 0.2^{\circ} \mathrm{C}$. Each gas-positive EC tube was plated onto eosin methylene blue agar (Difco) and incubated for $24 \mathrm{~h}$ at $35^{\circ} \mathrm{C}$. One E. coli isolate per each seawater sample was randomly selected and validated using the API 20E Kit (bioMerieux, Marcy-l'Etoile, France).

\section{Antimicrobial susceptibility testing}

Antimicrobial susceptibility testing against 22 antimicrobi- als was performed on $131 \mathrm{E}$. coli isolates using the disk diffusion method on Mueller Hinton agar plates (Difco), according to the standards and interpretive criteria of the Clinical and Laboratory Standards Institute (CLSI) (2010). The following 22 antibiotics were used: amikacin $(30 \mu \mathrm{g})$, amoxicillin (20 $\mu \mathrm{g})$, ampicillin $(10 \mu \mathrm{g})$, cefepime $(30 \mu \mathrm{g})$, cefotetan $(30 \mu \mathrm{g})$, cefoxitin $(30 \mu \mathrm{g})$, ceftriaxone $(30 \mu \mathrm{g})$, cephalothin $(30 \mu \mathrm{g})$, chloramphenicol $(30 \mu \mathrm{g})$, ciprofloxacin $(5 \mu \mathrm{g})$, erythromycin $(15 \mu \mathrm{g})$, gentamicin $(10 \mu \mathrm{g})$, imipenem $(10 \mu \mathrm{g})$, kanamycin $(30 \mu \mathrm{g})$, nalidixic acid $(30 \mu \mathrm{g})$, norfloxacin $(10 \mu \mathrm{g})$, rifampin $(5 \mu \mathrm{g})$, streptomycin $(10 \mu \mathrm{g})$, sulfamethoxazole/trimethoprim $(23.75 / 1.25 \mu \mathrm{g})$, tetracycline $(30 \mu \mathrm{g})$, ticarcillin $(75 \mu \mathrm{g})$, and trimethoprim $(5 \mu \mathrm{g})$. Antimicrobial susceptibility test discs were purchased from Oxoid Ltd. (Basingstoke, Hampshire, UK), and the results were classified as susceptible, intermediate, or resistant according to the zone diameter interpretive standards recommended by CLSI (2010). The quality-control strains, E. coli ATCC 25922 and Staphylococcus aureus ATCC 25923, were included in each run.

\section{PCR amplification of antimicrobial resistance and virulence genes}

The presence of genes associated with tetracycline (tet $A$, tet $B$, and tet $C$ ) or $\beta$-lactams (TEM, SHV, and OXA) in 44 tetracycline-resistant or 29 ampicillin-resistant isolates, respectively, were detected using PCR. All isolates were also evaluated by PCR for the following genes: heat labile (lt), heat stable (st), attaching and effacing (eae), EAEC-associated plasmid ( $p C V D 432)$, invasion-associated locus (ial), and Shiga toxin (stx1 and stx2) genes. PCR was performed using the primer sets listed in Table 1. Genomic DNA was extracted from overnight bacterial cultures using the boiling method. After cooling, samples were microcentrifuged to remove cell debris, and the resulting supernatants were used as PCR templates. In each PCR reaction, $3 \mu \mathrm{L}$ of the respective DNA template was suspended in $22 \mu \mathrm{L}$ reaction mixtures containing $2.5 \mu \mathrm{L}$ of $10 \times$ Ex Taq buffer (Takara, Kyoto, Japan), 50 pmol of each primer, $2 \mu \mathrm{L}$ of dNTPs (2.5 mM of each dNTP), and 2 units of Ex Taq DNA polymerase (5 U/ $\mu \mathrm{L})$. PCR amplification of tetracycline-associated genes was conducted under the following conditions: initial denaturation at $94^{\circ} \mathrm{C}$ for $5 \mathrm{~min} ; 30$ cycles of denaturation at $94^{\circ} \mathrm{C}$ for $30 \mathrm{~s}$, annealing at $50^{\circ} \mathrm{C}$ for $30 \mathrm{~s}$, and extension at $72^{\circ} \mathrm{C}$ for $1 \mathrm{~min}$; and a final extension step at $72^{\circ} \mathrm{C}$ for $10 \mathrm{~min}$. PCR amplification of $\beta$-lactam-associated genes was conducted under the following conditions: initial denaturation at $95^{\circ} \mathrm{C}$ for $5 \mathrm{~min}$; 30 cycles of denaturation at $94^{\circ} \mathrm{C}$ for $30 \mathrm{~s}$, annealing at $58^{\circ} \mathrm{C}$ for $15 \mathrm{~s}$, and extension at $72^{\circ} \mathrm{C}$ for $1 \mathrm{~min}$; and a final extension step at $72^{\circ} \mathrm{C}$ for $10 \mathrm{~min}$. PCR conditions for detecting virulence genes consisted of initial denaturation at $95^{\circ} \mathrm{C}$ for $5 \mathrm{~min}$, followed by 30 cycles of denaturation at $95^{\circ} \mathrm{C}$ for $30 \mathrm{~s}$, annealing at $52^{\circ} \mathrm{C}$ for $30 \mathrm{~s}$, and extension at $72^{\circ} \mathrm{C}$ for $1 \mathrm{~min}$. All PCR reactions were performed using the 
Gene Amp PCR System 9700 (Perkin Elmer, Norwick, CT, USA) and the amplified products were electrophoresed on $1.5 \%$ agarose gels stained with ethidium bromide and visualized under UV light.

\section{Results}

\section{Isolation of $E$. coli strains from surface seawater in Gomso Bay}

A sanitary survey in an important shellfish-growing area of Gomso Bay, west coast of Korea, was conducted to evaluate bay conditions and compliance with bacteriological criteria for shellfish production. Seawater samples were collected 12 times from May to December 2012 from 20 sampling stations established in the survey area (Fig. 1). The values determined by the MPN-method for both the total coliform bacteria and fecal coliform bacteria in the 240 seawater samples ranged from less than 1.8 to $240 \mathrm{MPN} / 100 \mathrm{~mL}$, respectively (Table 2). The geometric means and estimated 90th percentile values for total coliform bacteria ranged from 2.1 to $6.3 \mathrm{MPN} / 100 \mathrm{~mL}$, and from 3.3 to $38.8 \mathrm{MPN} / 100 \mathrm{~mL}$, respectively, whereas those for fecal coliform bacteria ranged from 1.9 to $4.1 \mathrm{MPN} / 100 \mathrm{~mL}$,

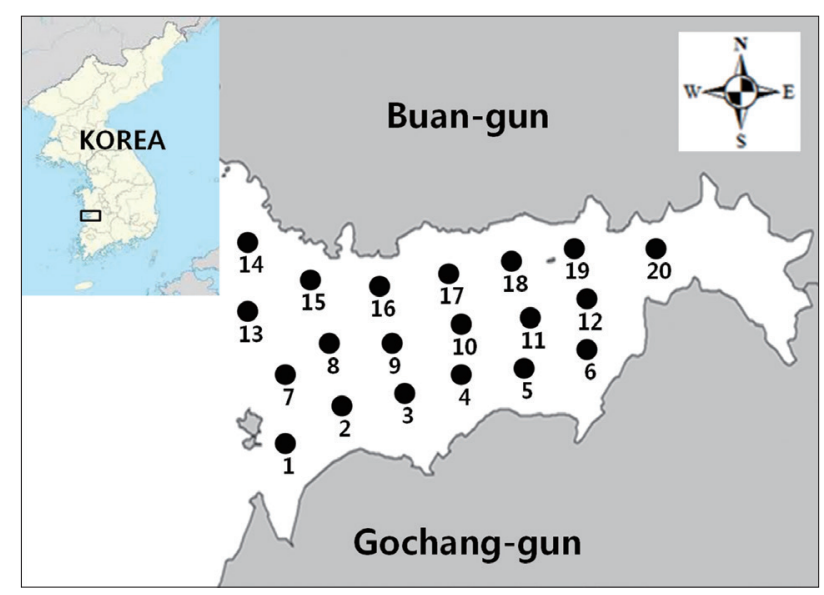

Fig. 1. Location of sample collection stations in Gomso Bay, Republic of Korea, from May to December 2012.

and from 2.7 to $18.9 \mathrm{MPN} / 100 \mathrm{~mL}$, respectively. Notably, the levels of total coliform and fecal coliform bacteria from stations near the wastewater discharge sites (stations 3, 14, 18, 19 , and 20) were slightly higher than those from other sites. The bacteria levels after rainfall were also higher, than those in

Table 1. Oligonucleotide primers used in this study

\begin{tabular}{|c|c|c|c|c|}
\hline Gene & Primer & Nucleotide sequence ( $5^{\prime}$ to $3^{\prime}$ ) & Size (bp) & Reference \\
\hline \multirow[t]{2}{*}{ tetA } & $\operatorname{tet}(\mathrm{A})-\mathrm{F}$ & GTGAAACCCAACATACCCC & 887 & Van et al., 2008 \\
\hline & $\operatorname{tet}(\mathrm{A})-\mathrm{R}$ & GAAGGCAAGCAGGATGTAG & & \\
\hline \multirow[t]{2}{*}{$\operatorname{tet} B$} & $\operatorname{tet}(\mathrm{B})-\mathrm{F}$ & CCTTATCATGCCAGTCTTGC & 773 & Van et al., 2008 \\
\hline & $\operatorname{tet}(\mathrm{B})-\mathrm{R}$ & ACTGCCGTTTTTTCGCC & & \\
\hline \multirow[t]{2}{*}{ tet $C$} & $\operatorname{tet}(\mathrm{C})-\mathrm{F}$ & ACTTGCAGCCACTATCGAC & 880 & Van et al., 2008 \\
\hline & $\operatorname{tet}(\mathrm{C})-\mathrm{R}$ & CTACAATCCATGCCAACCC & & \\
\hline \multirow[t]{2}{*}{ TEM } & TEM-F & GAGTATTCAACATTTTCGT & 857 & Van et al., 2008 \\
\hline & TEM-R & ACCAATGCTTAATCAGTGA & & \\
\hline \multirow[t]{2}{*}{ SHV } & SHV-F & TCGCCTGTGTATTATCTCCC & 768 & Van et al., 2008 \\
\hline & SHV-R & CGCAGATAAATCACCACAATG & & \\
\hline \multirow[t]{2}{*}{ OXA } & OXA-F & GCAGCGCCAGTGCATCAAC & 198 & Van et al., 2008 \\
\hline & OXA-R & CCGCATCAAATGCCATAAGCG & & \\
\hline \multirow[t]{2}{*}{ estA } & ST-F & GCTAAACCAGTAGGGTCTTCAAAA & 147 & Talukdar et al., 2013 \\
\hline & ST-R & CCCGGTACAGGCAGGATTACAACA & & \\
\hline \multirow[t]{2}{*}{ eltB } & LT-F & CACACGGAGCTCCTCAGTC & 508 & Talukdar et al., 2013 \\
\hline & LT-R & CCCCCAGCCTAGCTTAGTTT & & \\
\hline \multirow[t]{2}{*}{ eae } & eae-F & CCCGAATTCGGCACAAGCATAAGC & 881 & Talukdar et al., 2013 \\
\hline & eae- $\mathrm{R}$ & CCCGGATCCGTCTCGCCAGTATTCG & & \\
\hline \multirow[t]{2}{*}{ aat } & pCVD432-F & CTGGCGAAAGACTGTATCAT & 650 & Talukdar et al., 2013 \\
\hline & pCVD432-R & CAATGTATAGAAATCCGCTGTT & & \\
\hline \multirow[t]{2}{*}{ stxl } & $\operatorname{stx} 1 \mathrm{~F}$ & CACAATCAGGCGTCGCCAGCGCACTTGCT & 606 & Talukdar et al., 2013 \\
\hline & stx1R & TGTTGCAGGGATCAGTGGTACGGGGATGC & & \\
\hline \multirow[t]{2}{*}{ stx 2} & stx2F & CCACATCGGTGTCTGTTATTAACCACACC & 372 & Talukdar et al., 2013 \\
\hline & stx2R & GCAGAACTGCTCTGGATGCATCTCTGGTC & & \\
\hline \multirow[t]{2}{*}{$i a a$} & ial upper & CTGGATGGTATGGTGAGG & 320 & Talukdar et al., 2013 \\
\hline & ial lowe & GGAGGCCAACAATTATTTCC & & \\
\hline
\end{tabular}


the dry season. Based on these data, the bacteriological quality of seawater in Gomso Bay met the criteria recommended by the National Shellfish Sanitation Program (Food and Drug Administration, 2005) and the Korea Shellfish Sanitation Program for shellfish production (Ministry of Marine Affairs and Fisheries, 2006). One strain from each seawater sample was isolated to further analyze antimicrobial resistance and virulence genes in isolated $E$. coli strains.

\section{Antimicrobial susceptibility of $E$. coli isolates}

In total, 131 isolates were tested for resistance against 22 antimicrobial agents (Table 3). Resistance to tetracycline (33.6\%), ampicillin $(22.1 \%)$, ticarcillin $(22.1 \%)$, trimethoprim $(16.8 \%)$, sulfamethoxazole/trimethoprim (16.0\%), nalidixic acid (13.7\%), streptomycin (11.5\%), chloramphenicol (9.9\%), kanamycin $(7.6 \%)$, norfloxacin $(6.1 \%)$, ciprofloxacin $(2.3 \%)$, erythromycin $(2.3 \%)$, and gentamicin $(0.8 \%)$ was observed. These results are in agreement with several previous studies (You et al., 2006; Van et al., 2008; Koo and Woo, 2012; Ryu et al., 2012b). However, no isolate showed resistance to amikacin, amoxicillin, cefepime, cefotetan, cefoxitin, ceftri- axone, cephalothin, imipenem, or rifampin. Table 4 shows the resistance patterns of these isolates. Among the $131 \mathrm{E}$. coli isolates, $70(53.4 \%)$ were not resistant to any of the 22 antimicrobial agents tested, whereas $61(46.6 \%)$ were resistant to at least one antimicrobial agent. In total, $22.9 \%$ of the isolates were resistant to three or more classes of antimicrobials and defined as multidrug resistant. One strain, in particular, exhibited resistance to 11 antimicrobial agents (AMP, C, CIP, K, NA, NOR, S, SXT, TE, TIC, and TMP).

\section{Characterization of antimicrobial resistance genes in $E$. coli isolates}

Ampicillin-resistant isolates $(n=29)$ were investigated for the presence of $\beta$-lactamase-encoding genes using PCR with the primer sets specified in Table 1. We found that 27 isolates (93.1\%) contained genes encoding TEM-type $\beta$-lactamases, whereas the rest had genes associated with SHV-type $\beta$-lactamases (data not shown), consistent with previous findings indicating that the former genes were among the most prevalent in ampicillin-resistant $E$. coli isolates derived from food and livestock (Van et al., 2008; Aslam et al., 2009; Ryu

Table 2. Summary of bacteriological examination results of each sampling stations in Gomso Bay, from May to December 2012

\begin{tabular}{|c|c|c|c|c|c|c|c|c|c|c|c|}
\hline \multirow{4}{*}{ Station } & \multicolumn{10}{|c|}{ MPN/100mL } & \multirow{4}{*}{$\begin{array}{c}\text { No. of } \\
\text { samples }\end{array}$} \\
\hline & \multirow{3}{*}{ Range } & \multicolumn{3}{|c|}{ Total coliform } & & \multicolumn{5}{|c|}{ Fecal coliform } & \\
\hline & & \multirow{2}{*}{$\mathbf{G M}^{1)}$} & \multirow{2}{*}{$90 \mathrm{th}^{2)}$} & \multicolumn{2}{|c|}{$>\mathbf{2 3 0}$} & \multirow{2}{*}{ Range } & \multirow{2}{*}{$\mathbf{G M}^{1)}$} & \multirow{2}{*}{ 90th } & \multicolumn{2}{|c|}{$>43$} & \\
\hline & & & & No. & $\%$ & & & & No. & $\%$ & \\
\hline 1 & $<1.8-7.8$ & 2.1 & 4.0 & 0 & 0.0 & $<1.8-4.6$ & 1.9 & 2.7 & 0 & 0.0 & 12 \\
\hline 2 & $<1.8-79$ & 3.6 & 17.5 & 0 & 0.0 & $<1.8-13$ & 2.5 & 6.3 & 0 & 0.0 & 12 \\
\hline 3 & $<1.8-79$ & 3.6 & 18.5 & 0 & 0.0 & $<1.8-49$ & 3.0 & 11.2 & 1 & 8.3 & 12 \\
\hline 4 & $<1.8-33$ & 4.3 & 25.0 & 0 & 0.0 & $<1.8-23$ & 3.2 & 11.4 & 0 & 0.0 & 12 \\
\hline 5 & $<1.8-33$ & 3.5 & 15.2 & 0 & 0.0 & $<1.8-13$ & 2.8 & 7.6 & 0 & 0.0 & 12 \\
\hline 6 & $<1.8-79$ & 4.1 & 23.6 & 0 & 0.0 & $<1.8-13$ & 3.0 & 8.8 & 0 & 0.0 & 12 \\
\hline 7 & $<1.8-33$ & 3.0 & 11.0 & 0 & 0.0 & $<1.8-13$ & 2.4 & 5.5 & 0 & 0.0 & 12 \\
\hline 8 & $<1.8-33$ & 3.5 & 14.8 & 0 & 0.0 & $<1.8-33$ & 3.3 & 13.7 & 0 & 0.0 & 12 \\
\hline 9 & $<1.8-33$ & 3.4 & 12.5 & 0 & 0.0 & $<1.8-13$ & 2.7 & 6.9 & 0 & 0.0 & 12 \\
\hline 10 & $<1.8-23$ & 2.5 & 7.1 & 0 & 0.0 & $<1.8-7.8$ & 2.3 & 4.8 & 0 & 0.0 & 12 \\
\hline 11 & $<1.8-23$ & 2.7 & 8.2 & 0 & 0.0 & $<1.8-13$ & 2.4 & 5.7 & 0 & 0.0 & 12 \\
\hline 12 & $<1.8-13$ & 2.7 & 7.3 & 0 & 0.0 & $<1.8-7.8$ & 2.3 & 4.8 & 0 & 0.0 & 12 \\
\hline 13 & $<1.8-4.6$ & 2.1 & 3.3 & 0 & 0.0 & $<1.8-4.5$ & 1.9 & 2.7 & 0 & 0.0 & 12 \\
\hline 14 & $<1.8-49$ & 4.8 & 33.4 & 0 & 0.0 & $<1.8-49$ & 2.9 & 12.7 & 0 & 0.0 & 12 \\
\hline 15 & $<1.8-130$ & 6.3 & 38.8 & 0 & 0.0 & $<1.8-23$ & 4.1 & 15.0 & 0 & 0.0 & 12 \\
\hline 16 & $<1.8-13$ & 3.2 & 9.4 & 0 & 0.0 & $<1.8-7.8$ & 2.3 & 4.8 & 0 & 0.0 & 12 \\
\hline 17 & $<1.8-13$ & 2.5 & 6.3 & 0 & 0.0 & $<1.8-4.5$ & 2.2 & 3.9 & 0 & 0.0 & 12 \\
\hline 18 & $<1.8-240$ & 3.2 & 21.0 & 1 & 8.3 & $<1.8-240$ & 2.9 & 17.8 & 1 & 8.3 & 12 \\
\hline 19 & $<1.8-240$ & 3.3 & 25.6 & 1 & 8.3 & $<1.8-240$ & 3.0 & 18.9 & 1 & 8.3 & 12 \\
\hline 20 & $<1.8-240$ & 3.6 & 27.4 & 1 & 8.3 & $<1.8-130$ & 3.0 & 16.2 & 1 & 8.3 & 12 \\
\hline Total & $<1.8-240$ & 3.4 & 16.5 & 3 & 1.3 & $<1.8-240$ & 2.7 & 9.1 & 4 & 1.7 & 240 \\
\hline
\end{tabular}

${ }^{1)}$ geometric mean. ${ }^{2)}$ The estimated 90th percentile. 
et al., 2012b).

Among the 44 tetracycline-resistant $E$. coli isolates, the tet $A$ and tet $C$ genes were found in $35(79.5 \%)$ and $19(43.2 \%)$ isolates, respectively, and tetB was found in only $3(6.8 \%)$. Fourteen isolates $(31.8 \%)$ tested positive for both tet $A$ and tetC. Our results also showed that three tetracycline-resistant isolates possessed none of the tetracycline resistance genes analyzed (tet $A$, tet $B$, or tet $C$ ) (data not shown). These findings were consistent with previous studies demonstrating that genes encoding active efflux pumps of tetracycline, such as tet $A-E$ and $\operatorname{tet} G$, occurred frequently among tetracycline-resistant $E$. coli isolates derived from livestock and aquaculture environments (Van et al., 2008; Aslam et al., 2009; Tang et al., 2011; Koo and Woo, 2012; Ryu et al., 2012b).

\section{Detection of virulence genes by PCR}

All 131 isolates were also examined for the presence of seven virulence genes (lt, st, eae, pCVD432, ial, stxl, and stx2) using PCR. Approximately $3.1 \%(n=4)$ of the isolates were positive for at least one of the seven virulence genes specific to certain E. coli pathotypes. Only $0.8 \%(n=1)$ and

Table 3. Antimicrobial resistance of Escherichia coli isolated from surface seawater in Gomso Bay

\begin{tabular}{|c|c|c|c|}
\hline \multirow{2}{*}{ Antimicrobials } & \multicolumn{3}{|c|}{ No. of isolates } \\
\hline & Resistant & Intermediate & Susceptible \\
\hline Amikacin & 0 & 78 & 53 \\
\hline Amoxicillin & 0 & 0 & 131 \\
\hline Ampicillin & 29 & 37 & 65 \\
\hline Cefepime & 0 & 10 & 121 \\
\hline Cefotetan & 0 & 2 & 129 \\
\hline Cefoxitin & 0 & 0 & 131 \\
\hline Ceftriaxone & 0 & 0 & 131 \\
\hline Cephalothin & 0 & 80 & 51 \\
\hline Chloramphenicol & 13 & 23 & 95 \\
\hline Ciprofloxacin & 3 & 16 & 112 \\
\hline Erythromycin & 3 & 128 & 0 \\
\hline Gentamicin & 1 & 30 & 100 \\
\hline Imipenem & 0 & 0 & 131 \\
\hline Kanamycin & 10 & 89 & 32 \\
\hline Nalidixic acid & 18 & 60 & 53 \\
\hline Norfloxacin & 8 & 30 & 93 \\
\hline Rifampin & 0 & 108 & 23 \\
\hline Streptomycin & 15 & 110 & 6 \\
\hline $\begin{array}{l}\text { Sulfamethoxazole/ } \\
\text { Trimethoprim }\end{array}$ & 21 & 43 & 67 \\
\hline Tetracycline & 44 & 28 & 59 \\
\hline Ticarcillin & 29 & 3 & 99 \\
\hline Trimethoprim & 22 & 29 & 80 \\
\hline
\end{tabular}

$2.3 \%(n=3)$ of the isolates were positive for the EAEC-associated plasmid ( $p C V D 432)$ and the EPEC-specific attaching and effacing (eae) genes, respectively (data not shown). However, the STEC-associated stx 1 and stx2 virulence genes, the ETEC-specific heat-stable toxin (ST) and heat-labile toxin (LT) genes, and the EIEC-specific invasion-associated locus (ial) gene were not detected. These results imply that none of the isolates were of the STEC, ETEC, or EIEC pathotype. The virulence gene frequency in the 131 isolates of this study was lower than that reported previously (Ram et al., 2008; Van et al., 2008; Talukdar et al., 2013).

\section{Discussion}

Our current study focused primarily on the prevalence of E. coli in Gomso Bay as well as the characterization of antimicrobial resistance and virulence genes in these isolates. Gomso Bay, connected to the Yellow Sea, is located between Gochang-gun and Buan-gun in Jeollabuk-do, Korea, covering approximately $76 \mathrm{~km}^{2}$ with an average width, length, and depth of 5-6 km, $17 \mathrm{~km}$, and 2-3 m, respectively. The bay is
Table 4. Antimicrobial resistance patterns of Escherichia coli isolated from surface seawater in Gomso Bay

\begin{tabular}{rlc}
\hline \multicolumn{1}{c}{ Resistance type } & $\begin{array}{c}\text { No. of } \\
\text { resistant strains }\end{array}$ \\
\hline 1 & TE & 17 \\
2 & C & 4 \\
3 & NA & 4 \\
4 & AMP & 1 \\
5 & TIC & 1 \\
6 & TE-C & 1 \\
7 & TE-S & 1 \\
8 & AMP-TIC & 1 \\
9 & TMP-SXT & 1 \\
10 & TE-AMP-TIC & 1 \\
11 & TMP-SXT-S & 1 \\
12 & TE-AMP-TIC-S & 4 \\
13 & TE-AMP-TIC-C & 1 \\
14 & TE-TMP-SXT-K & 1 \\
15 & AMP-TIC-TMP-SXT & 1 \\
16 & TE-AMP-TIC-NA-K & 1 \\
17 & TE-AMP-TIC-NA-S & 1 \\
18 & TE-AMP-TIC-S-C & 1 \\
19 & AMP-TIC-TMP-SXT-S & 1 \\
20 & TE-TIC-TMP-SXT-S-C & 1 \\
21 & TE-AMP-TMP-SXT-S-C & 1 \\
22 & TE-AMP-TIC-TMP-NA-S & 1 \\
23 & AMP-TIC-TMP-SXT-K-C & 1 \\
24 & TE-AMP-TIC-TMP-SXT-NA & 2 \\
25 & TE-AMP-TIC-TMP-SXT-K & 1 \\
26 & TE-AMP-TIC-TMP-SXT-S-C & 1 \\
27 & AMP-TIC-TMP-SXT-NA-K-NOR & 1 \\
28 & TE-AMP-TIC-TMP-SXT-NA-NOR & 2 \\
29 & TE-AMP-TIC-TMP-SXT-NA-GM & 1 \\
30 & TE-AMP-TIC-TMP-SXT-NA-K-NOR-S \\
31 & TE-AMP-TIC-TMP-SXT-NA-K-NOR-C-E \\
32 & TE-AMP-TIC-TMP-SXT-NA-K-NOR-CIP-E & 1 \\
33 & TE-AMP-TIC-TMP-SXT-NA-K-NOR-CIP-C-S & 2 \\
Total & & 61 \\
\hline & & 1 \\
\hline
\end{tabular}


a source of shellfish and other aquaculture organisms. Waste from agriculture, household and stock breeding of numerous small rivers that flow into Gomso Bay are thought to be the current source of contaminants in the area.

Virulent or antimicrobial-resistant bacteria in drainage water can contaminate shellfish and fisheries in the bay and potentially be hazardous for human health. Many antibiotics are used for therapeutic treatment and prophylactic purposes in animals and humans; consequently, increase in antimicrobial resistance due to excess use and misuse of antimicrobials is a public health concern (World Health Organization, 2001). Therefore, antimicrobial usage in animal feed should be tightly regulated to decrease the prevalence of antimicrobialresistant bacteria.

In this study, 131 environmental $E$. coli strains isolated from surface seawater of Gomso Bay were tested for resistance against 22 antimicrobial agents. Tetracycline resistance was most prevalent, followed by that to ampicillin, ticarcillin, trimethoprim, sulfamethoxazole/trimethoprim, nalidixic acid, and streptomycin. Of the 61 isolates displaying resistance to at least 1 antimicrobial, resistance patterns varied and were classified among 33 types (Table 4 ).

Ampicillin resistance in gram-negative bacteria is primarily mediated by $\beta$-lactamases, which hydrolyze the $\beta$-lactam ring and thereby inactivate antibiotics (Massova and Mobashery, 1998). In many genera of gram-negative bacteria, the most predominant $\beta$-lactamases are TEM-, SHV-, CTX-, and OXA-type enzymes (Bradford, 2001). TEM-1, a plasmid-mediated $\beta$-lactamase, is the most common $\beta$-lactamase in gram-negative bacteria, and accounts for up to $90 \%$ of the ampicillin resistance in $E$. coli (Livermore, 1995). In the present study, we found the TEM-type $\beta$-lactamases to be the most prevalent among 29 ampicillin-resistant isolates, consistent with previous studies (Livermore, 1995; Van et al., 2008; Aslam et al., 2009; Ryu et al., 2012b). In addition, both the tet $A$ and tet $C$ genes prevailed among the 44 tetracyclineresistant $E$. coli isolates. In the analyses of virulence genes, only $3.1 \%$ of the isolates were positive for the EAEC-associated plasmid ( $p C V D 432)$ and the EPEC-specific attaching and effacing (eae) genes.

$E$. coli is a facultative anaerobic bacterium found in the normal intestinal flora in humans and animals, however, some toxic strains can induce pathogenicity ranging from mild diarrhea to fatal complications (Tannock, 1995; Clements et al., 2012). While we did not investigate the mechanisms underlying the development of antimicrobial resistance in these $E$. coli isolates, several previous studies have established a causal relationship between antimicrobial use in aquaculture and the increase in specific antimicrobial-resistant bacterial strains (Schmidt et al., 2001; Petersen et al., 2002; Ribeiro et al., 2010; Ye et al., 2013).

In conclusion, continuous surveillance of antimicrobialresistant bacteria in Gomso Bay is necessary to ensure the safety of fisheries and shellfish production.

\section{Acknowledgements}

This work was funded by a grant from the National Fisheries Research and Development Institute of Korea.

\section{References}

Aarestrup FM. 2005. Veterinary drug usage and antimicrobial resistance in bacteria of animal origin. Basic Clin Phamacol Toxicol 96, 271281.

American Public Health Association. 1970. Recommended Procedures for the Examination of Sea Water and Shellfish, 4th ed. American Public Health Association, Washington, DC. US.

Aslam M, Diarra MS, Service C and Rempel H. 2009. Antimicrobial resistance genes in Escherichia coli isolates recovered from a commercial beef processing plant. J Food Prot 72, 1089-1093.

Bradford PA. 2001. Extended-spectrum $\beta$-lactamases in the 21 st century: characterization, epidemiology, and detection of this important resistance threat. Clin Microbiol Rev 14, 933-951.

Clements A, Young JC, Constantinou N and Frankel G. 2012. Infection strategies of enteric pathogenic Escherichia coli. Gut Microbes 3, 71-87.

Clinical and Laboratory Standards Institute (CLSI). 2010. Performance Standards for Antimicrobial Susceptibility Testing. CLSI document M100-S20. Clinical and Laboratory Standards Institute, Wayne, PA. US.

Food and Drug Administration. 2005. National Shellfish Sanitation Program (NSSP) Guide for the Control of Molluscan Shellfish. II. Growing Areas. Food and Drug Administration, Washington, DC, US, pp. 199-204.

Hammerum AM and Heuer OE. 2009. Human health hazards from antimicrobial-resistant Escherichia coli of animal origin. Clin Infect Dis $48,916-921$.

Koo HJ and Woo GJ. 2011. Distribution and transferability of tetracycline resistance determinants in Escherichia coli isolated from meat and meat products. Int J Food Microbiol 145, 407-413.

Koo HJ and Woo GJ. 2012. Characterization of antimicrobial resistance of Escherichia coli recovered from foods of animal and fish origin in Korea. J Food Prot 75, 966-972.

Lang MM, Ingham SC and Ingham BH. 1999. Verifying apple cider plant sanitation and hazard analysis critical control point programs: choice of indicator bacteria and testing methods. J Food Prot 62, 887-893.

Livermore DM. 1995. $\beta$-lactamases in laboratory and clinical resistance. Clin Microbiol Rev 8, 557-584.

Martinez JL. 2009. The role of natural environments in the evolution of resistance traits in pathogenic bacteria. Proc Biol Sci 276, 25212530.

Massova I and Mobashery S. 1998. Kinship and diversification of bacterial penicillin-binding proteins and $\beta$-lactamases. Antimicrob Agents Chemother 42, 1-17.

Ministry of Marine Affairs and Fisheries. 2006. Sanitary Criteria of Producing · Processing Facilities and Sea Water Area for Fisher- 
ies Products. The notification of Ministry of Maritime Affairs and Fisheries, Article 2006-74. Ministry of Marine Affairs and Fisheries, Seoul, KR.

Petersen A, Andersen JS, Kaewmak T, Somsiri T and Dalsgaard A. 2002. Impact of integrated fish farming on antimicrobial resistance in a pond environment. Appl Environ Microbiol 68, 6036-6042.

Ram S, Vajpayee P and Shanker R. 2008. Contamination of potable water distribution systems by multiantimicrobial-resistant enterohemorrhagic Escherichia coli. Environ Health Perspect 116, 448-452.

Ribeiro RV, Reis EMF, Reis CMF, Freitas-Almeida AC and Rodrigues DP. 2010. Incidence and antimicrobial resistance of enteropathogens isolated from an integrated aquaculture system. Lett Appl Microbiol 51, 611-618.

Rosas I, Salinas E, Martinez L, Calva E, Cravioto A, Eslava C and Amabile-Cuevas CF. 2006. Urban dust faecal pollution in Mexico City: antibiotic resistance and virulence factors of Escherichia coli. Int J Hyg Environ Health 209, 461-470.

Rowe-Magnus DA, Guerout AM and Mazel D. 2002. Bacterial resistance evolution by recruitment of super-integron gene cassettes. Mol Microbiol 43, 1657-1669.

Ryu SH, Lee JH, Park SH, Song MO, Park SH, Jung HW, Park GY, Choi SM, Kim MS, Chae YZ, Park SG and Lee YK. 2012a. Antimicrobial resistance profiles among Escherichia coli strains isolated from commercial and cooked foods. Int J Food Microbiol 159, 263-266.

Ryu SH, Park SG, Choi SM, Hwang YO, Ham HJ, Kim SU, Lee YK, Kim MS, Park GY, Kim KS and Chae YZ. 2012b. Antimicrobial resistance and resistance genes in Escherichia coli strains isolated from commercial fish and seafood. Int J Food Microbiol 152, 1418.

Sapkota A, Sapkota AR, Kucharski M, Burke J, McKenzie S, Walker P and Lawrence R. 2008. Aquaculture practices and potential human health risks: current knowledge and future priorities. Environ Int 34, 1215-1226.

Schmidt AS, Bruun MS, Dalsgaard I and Larsen JL. 2001. Incidence, distribution, and spread of tetracycline resistance determinants and integron-associated antibiotic resistance genes among motile aeromonads from a fish farming environment. Appl Environ Microbiol $67,5675-5682$.

Stokes HW and Hall RM. 1989. A novel family of potentially mobile DNA elements encoding site-specific gene-integration functions: integrons. Mol Microbiol 3, 1669-1683.

Talukdar PK, Rahman M, Rahman M, Nabi A, Islam Z, Hoque MM, Endtz HP and Islam MA. 2013. Antimicrobial resistance, virulence factors and genetic diversity of Escherichia coli isolates from household water supply in Dhaka, Bangladesh. PLoS One 8, e61090.

Tang X, Tan C, Zhang X, Zhao Z, Xia X, Wu B, Guo A, Zhou R and Chen H. 2011. Antimicrobial resistances of extraintestinal pathogenic Escherichia coli isolates from swine in China. Microb Pathog 50, 207-212.

Tannock GW. 1995. Normal Microflora: An Introduction to Microbes Inhabiting the Human Body. Chapman and Hall, London, GB.

Turner SM, Scott-Tucker A, Cooper LM and Henderson IR. 2006. Weapons of mass destruction: virulence factors of the global killer enterotoxigenic Escherichia coli. FEMS Microbiol Lett 263, 1020.

Van TTH, Chin J, Chapman T, Tran LT and Coloe PJ. 2008. Safety of raw meat and shellfish in Vietnam: an analysis of Escherichia coli isolations for antibiotic resistance and virulence genes. Int J Food Microbiol 124, 217-223.

World Health Organization. 2001. Global Strategy for Containment of Antimicrobial Resistance. Publication nr WHO/CDS/CSR/ DRS/2001.2a, World Health Organization, Geneva, CH.

Ye L, Lu Z, Li X, Shi L, Huang Y and Wang HH. 2013. Antibioticresistant bacteria associated with retail aquaculture products from Guangzhou, China. J Food Prot 76, 295-301.

You JY, Moon BM, Oh IG, Baek BK, Li LG, Kim BS, Stein BD and Lee JH. 2006. Antimicrobial resistance of Escherichia coli $\mathrm{O} 157$ from cattle in Korea. Int J Food Microbiol 15, 74-78. 